\title{
FATHER AS A MUSE IN A HOUSE FOR MR BISWAS ${ }^{1}$
}

\author{
Reyban ÖZER-TANIY $A N^{2}$
}

\begin{abstract}
A House for Mr Biswas is the tragicomic tale of a lifetime struggle of Mr Biswas. It deals with the biography of V.S. Naipaul and his family. The story is mostly constructed around his father's lifetime experiences ranging from failures to important decisions. Briefly, in general, it comes from Naipaul's father, who deeply influenced him in his literary career. The question discussed here is how Naipaul's father shows itself in his literary career. The answer lies in the literary stance of Naipaul. In most of his works, he undermines the father image in a family by referring to his father's failures. However, the striking point is that no matter how badly Naipaul represents fathers in his works, he owes much to his father. To show his gratitude towards his father, he revisits the story of him in the early works of his writing career. He uses his father's personal history as his material, especially for his first books. Being educated firstly by his father, he achieves great literary success in his life, and therefore, this paper aims to address Naipaul's father as his literary muse. To support the claim of the constructive influence of fathers on their sons, the studies of newly emerged theories on the father-son relationship will be used as the theoretical frame.
\end{abstract}

Keywords: V.S Naipaul, Father, Son, A House For Mr Biswas, Muse, Writing

\section{A HOUSE FOR MR BISWAS’TA İLHAM PERİSİ OLARAK BABA}

\section{Öz}

A House for Mr Biswas, Bay Biswas'in hayat boyu mücadelesinin trajikomik bir hikâyesidir. Eser, Naipaul'un babasının başarıları ve kararları çerçevesinde oluşturulmuş bir aile biyografisidir. Kaynağını Naipaul'u edebi kariyerinde onu etkileyen babasından almaktadır. Çalışmada ele alınan soru ise babasının Naipaul'un edebi kariyerinde nasıl kendini gösterdiğidir. Cevap yazarın

\footnotetext{
1 This article is a revised version of the paper presented at the conference, "Focus on Fathers: Fatherhood in Contemporary Discourse," in 2015 at University of Wroclaw, Poland.

2 Asst. Prof. Dr. Pamukkale University, rotaniyan@pau.edu.tr, ORCID: 0000-0002-0285-1787
} 
duruşunda gizlidir. Eserlerinin birçoğunda, babasının başarısızlıklarına gönderme yaparak ailedeki baba imgesini baltalamaktadır. Çarpıcı nokta ise her ne kadar Naipaul babasını bazı eserlerinde kötü yansıtsa da babasına çok şey borçludur. Bu borçluluğu, yazar edebi hayatının ilk ürünlerinden olan kitaplarında işlemiştir. Babasının kişisel hikâyesini ilk eserlerinde konu olarak kullanmıştır. İlk olarak babası tarafından eğitilen yazar, yaşamında büyük bir edebi başarıya ulaşmışıı ve bu sebeple bu çalışmanın amacı Naipaul'un babasını onun edebi ilham perisi olarak işaret etmektir. Tüm bu söylemler ise daha yeni çalışılmaya başlanan baba- oğul ilişkilerinin akademik tartışmaları ile de çerçevelendirilecektir.

Anahtar Kelimeler: V.S Naipaul, Baba, Oğul, A House For Mr Biswas, İlham perisi, Yazmak

As a controversial writer of the post-1950s, V.S. Naipaul is being discussed by the authorities of postcolonial studies not only because of his discourse but also his literary stance in the field. Naipaul is condemned as an assimilated figure, and "many assumed Naipaul was himself an imitation colonialist" (King, 2003: p. 2), but indeed, he reflects merely the duality of postcolonial identity. Both his alienation and critical discourse with his "malicious tongue", though often seems hostile, bear the traces of a first-generation colonial who tries to keep a distance from his roots and the freedom of self-expression (King, 2003: p. 2) ${ }^{3}$. His discourse and variation in his works are, indeed, the representation of a man's soul with all contradictions, divergence, and repetitions. Therefore, "every book is quite different from the other" (Mystic Masseur, 1957: p. 44). However, a greater part of his works has autobiographical elements that explicitly overlap with his life. The main plot of his most works is furnished by his memories, historical figures and events, his hometown, and his family. As the most known example, $A$ House for $\mathrm{Mr}$ Biswas $^{4}$ is directly devoted to his father, and it is known that the whole story follows the significant events of his father, Seepersad Naipaul, and his life. Although the novel illustrates the ups and downs in a father and son relationship, it hints at the influence of a father on his son and his future literary works. The influence of Father Naipaul is not deniable. Yet, the main question here is whether his father is a constructive figure in Naipaul's character, notably literary character, and his discourse in his narrative or not. Naipaul frequently explains that he owes too much to his father in the act of writing and that his father plays the role of stimulating force in his writing career, especially in his first novels that focus on Trinidadian stories. He clearly expresses that:

The writing that has mattered most to me is that of my father, which has never been published. It taught me to look at things that had never been written about before and seemed dull in life, yet when transformed to paper became very surprising. A great deal of my vision of Trinidad has come straight from my father (Bingham,1972: p. 306).

\footnotetext{
${ }^{3}$ Explained in detail in the unpublished thesis of the writer.

${ }^{4}$ Hereafter will be abbreviated as $H B$.
} 
Hence, he devotes his novel, A House for Mr Biswas, to his father and his days in his hometown Trinidad. Therefore, the main motive of this study is to show the father-son relationship of Naipauls and its reflection on the life and career of V.S. Naipaul.

It is a generally acclaimed tendency to discuss parental influence on children by highlighting the relationship between mother and children". With the "changing culture of fatherhood" (Morman \& Floyd, 2002: p. 400), the studies focusing on fathers gradually increased and with the depictions of the modelled fathers who are more affectionate in the patterns of the parent-children studies (Lamb, 2010). J.H. Pleck issues the influence of fathers on their children with two hypotheses: the essential father and the important father hypotheses. The essential father model stands for the fathers who make a masculine contribution to child development, while the important father is good fathering like mothering. Thus, the important father promotes a good child (2010: pp. 27-57). Although supportive studies highlight the importance of fathers being involved in child development, there is an ongoing debate in articulating good and bad fathering. However, it is stated that sensitive fathers who talk to children, support, and encourage them to learn new things contribute a lot to their social and cognitive wellbeing (Easterbrooks \& Goldberg, 1984: pp. 740 - 752). Relatively, with their functions as role models, fathers have a huge importance in children's lives. Likewise, Naipaul's father as his role model at the beginning of his writing career has great importance in his life. Moreover, as claimed by the scholars, the healthy relationship of father-son has important outcomes in son's life:

One very key element in the formation of men's relationships is the relationship between son and father $[\ldots]$ this relationship influences everything in a man's life, from the way he sees himself inside to the way he sees all other people, power, economics, politics, and even his vision of the natural world (Vogt and Surridge, 1991: p. 6)

In addition, positive father-son relationships positively reflect sons' academic achievement (Singer \& Weinstein, 2000). This is the case with Naipaul. The positive relationship with his father has a direct influence on his writing career. He declares the role of his father in his life and his early writing career: "My father was extremely important $[\ldots]$ nearly everything that I am. I am because of this great link I felt with him, and a lot of my work" (Bates, 1963: p. 13). These lines indicate the explicit confession of Naipaul and the debt that he owes to his father in his challenging journey to become a writer. This debt he has acknowledged in his "Prelude to an Autobiography" investigates his literary beginnings utilizing an exploration of his father's life. He

\footnotetext{
${ }^{5}$ For further information please see, Chodorow, 1978, King, Abrams, Dowling, \& Brinich, 2009.
} 
acknowledges that his father has a great role in his life, and he avows that his childhood is shaped by his father.

In his novel, Naipaul portrays his father as a representative figure of a colonised man with a determinant stance in a multifaceted society and turns his father into a protagonist who is in-between with the impositions of the coloniser and the restrictions of the colonised. However, Mr Biswas, his fictionalised father, is always fond of writing and reading despite all the difficulties. Naipaul stresses this characteristic of his father and his great enthusiasm for writing in the novel with the relationship between Mr Biswas and his son Anand, the fictional Naipaul. In the foreword that Naipaul writes to the 1983 edition of the novel, he adds the explanation that "of all my books, this is the one that is closest to me. It is the most personal, created out of what I saw and felt as a child" (Naipaul, 1983: p. 22). This novel which is created out of the memories of childhood of Naipaul and adult fantasies of a writer serves both a homage and a reproach to his father in a personal way as his father strictly advised. As can be learned through the letters of his father to Naipaul - when he is in England for his education - his father encourages Naipaul and advises him about writing:

Don't be scared of being an artist. [...] Long years ago, when I was about 14 or 16, I felt much as you are feeling now; eager to write but writing in a kind of vacuity - utterly fictitious efforts - because what I wrote or tried to write had nothing to do with flesh and blood. I was simply writing stories that had no real counterpart to life. [...] In a sense I am wholly myself and yet I am wholly the character I am trying to portray. [...] This, I think is the secret of getting to the inside of things. The mere fact that you are conscious of this lack shows that you are on the right track. [...] One cannot write well unless one can think well; only in writing fiction one must be able to think as the character would think in given circumstances (Naipaul, 2000: p. 24).

Blending his personal experiences with an encouraging talk, his father advises his son to be a fictitious character in writing. He believes that such a characteristic is the key to being successful. The striking point here is that his father leads his son to the right way by sharing his unsuccessful attempts and mistakes in life. Moreover, again in a letter to his son, his father gives a general idea or stimulating force that in the following years, Naipaul will use as his literary style.

If you can bring the same quality of spontaneity in whatever you write everything will have a sparkle. I believe this free flow in one's written thought is due largely to the absence of anxiety. I know because it happens to me. Whenever I allow myself to become too anxious to please the person I am writing to or the person I am writing for, I generally lose balance and spoil everything. [...] Don't care to please any person but yourself. Only see that you have succeeded in saying exactly what you wanted to say - without showing off with utter brave sincerity - and you will have achieved style because you will have been yourself. [...] You must be yourself you must be sincere you must aim to say only what you have to say and to say it clearly. If in the chase for clarity you have to ignore a rule of grammar ignore it (Naipaul, 2000: 29). 
Naipaul takes his father's advice as his motto. He behaves as what his father has told him even in his novel on his father. He wants to write a homage to his father, but in his unique way as his father has already told him to do. Thus, he writes his father's story by following the contours of his father's life in A House for Mr Biswas. The account of Seepersad's life is derived from Naipaul's "Prelude to an Autobiography" and the foreword of his father's book, The Adventures of Gurudeva. It is known that Seepersad Naipaul was born in 1906. His father was a pundit and died when Seepersad was young; thus, the family was left in poverty. Seepersad's older brother was sent to work in the cane fields to make a living while Seepersad got an education.

The attempts to make him a pundit failed in the end. He tried his hand in different jobs, such as drawing signs for wealthy family members. One of these families was his wife's family. Through this job, he married Droapatie, a member of the wealthy Capildeo family ${ }^{6}$. Compared to his fictitious character, both Naipaul's father and Mr Biswas have many things in common. Both were born and bred in a village. Mr Biswas and Naipaul's father worked as a sign painter and married a wealthy and conservative Hindu girl. Both have breakdowns, both hold a series of jobs, both worked as journalists, and both wandered from one house to another. Like Mohun Biswas, Seepersad Naipaul works at a newspaper agency after moving to Port of Spain. Both wrote stories and transferred their ambitions to a talented son who left the island on a scholarship. Both lived in a succession of houses, moving from their wife's family house in the country and then in Port of Spain to an old estate house and back, before finally acquiring a house of their own.

The two older children, on whom Mr Biswas might have depended, were both abroad on scholarships. [...] He thought of the house as his own, though for years it had been irretrievably mortgaged. And during these months of illness and despair, he was struck again and again by the wonder of being in his own house, the audacity of it: [...] to hear no noises except those of his family, to wander freely from room to room and about his yard (Naipaul, 1961: pp. 7 - 8).

From the outset of the story, Mr Biswas is portrayed as an unsuccessful immigrant man who is constantly on the move to identify his place in the colonised world of Trinidad. At the last stage of his lifetime, Mr Biswas is depicted as an exhausted but happy man who achieves to have a house and has faith in his son who is studying abroad. Hence, this son whom his father has great faith and hope writes this novel to pay homage to his father's memory and writing. However, paradoxically, his son portrays in his fictional father who is a man incapable of his literary achievement and even tempers tenderness with mockery. He is portrayed as a man who "dangled all his life in a half-dependence and half-esteem" (Finding Centre, 1984: p. 34). When such a paradox is handled, Naipaul expresses his satirical tendencies to his father's illustration

\footnotetext{
${ }^{6}$ For further information please see: https://humanities.byu.edu/the-literary-journalism-of-seepersad-naipaul/
} 
with the influence of his father: "I was always very critical, liable to too easy a contempt. I think this is something my father gave me. My father was a defeated man: I think contempt was all that he could teach me, and I was contaminated by this" (Bingham, 1972: p. 306).

Whatever the satirical tendencies in Naipaul's portrayal of Seepersad's fictional counterparts, most of his references to his father are unambiguously respectful. He writes this novel as his father suggests, and, therefore, he tries to think of himself as his main character. As quoted before, his father always tells him to write freely without needing to please anyone and suggests thinking like the character himself. With these bits of advice, Naipaul creates an implicit connection between Anand and Mr Biswas, the father, and son in the novel, which indicates the connection or a tie in which he places himself in his father's shoes just as his father advises for his writing. Thus, Anand's life both repeats and transcends that of Mr Biswas. For instance, Anand's physical frailty is emphasized in the novel: "[T] he boy's narrow shoulder blades below the thin cotton shirt; the slender neck, the large head; the thin eczema-stained legs in small, loose trousers; the blackened soles" (HB, 1961: p. 211). Anand's ill-fitting and ungainly home-made clothes remind that of Mr Biswas's when he wears flour sack trousers: "His pants, made by Bipti from flour sacks, were unfortunate. Despite many washings they were still bright with letters and even whole words" (HB, 1961: p. 103). Likewise, Anand's clothes are made by his mother and their bad condition recalls Mr Biswas's clothes that he used when he was a child.

Mr Biswas was irritated by his shyness, but he was again touched by the boy's fragility and the carefully ragged home clothes which Anand, like the other children, wore the minute he came from school. Anand's washed-out khaki shorts were spectacularly patched, had slits but no pockets and a gaping empty fob. His shirt was darned and frayed and the collar was chewed; from the crooked stitches, the irregular cut, the weak and absurd decoration on the pocket Mr Biswas could tell that the shirt had been made by Shama (HB, 1961: p. 213).

Moreover, the scene of Anand's humiliation at school when he is "frightened to use the school WC" (HB, 1961: p. 235) and wet himself, which directly echoes that of Mr Biswas's humiliation at Pundit Jairam's. Mr Biswas “became the buffoon. He told about his misadventure at Pundit Jairam's" (HB, 1961: p. 235) to share his son's sorrow and embarrassment. Like these examples, there are many other events that father and son share. In these similarities between them, there is always intimacy. His son feels pain when other members of the Tulsi family mock his father.

Moreover, there are times when his son stands by his father when his family agrees to abandon him at Green Vale. A succession of advances and retreats characterizes Mr Biswas's relationship with his son. Even when he stands by his father, he does so petulantly: "[sic] Because - the word came out thin, explosive, charged with anger, at himself and his father. Because they 
were going to leave you alone" (HB, 1961: p. 251). These are examples of the most intimate representations of a father and son relationship. Naipaul describes this relationship with his father as a protective relationship in his life in which he is responsible and caring: "what is odd about it is that I always felt protective towards my father. I never felt that he was the man protecting me, I always felt quite the other way around: that it was up to me to look after him" (Bingham, 1972: p. 306). Such a responsibility towards his father might seem humiliating and destructive in the relationship between father and son. Still, Naipaul's feelings for his father and his sense of protection and care can also be read as a constructive and intimate relationship. With such an instinct, Naipaul feels the obligation to look after his father's literary writings. In a letter written by him, it is seen that he gives advice on his father's writing and tries to encourage about writing his father as well: "I have written ten stories so far. You know that I can't write well. Not half as well as you. You manage a type of humour I cannot manage” (Naipaul, 2000: p. 193).

This letter indicates the link between father and son and points out that their tie is constructed on the writing and general terms on education. It can be easily deduced that the whole letters between Naipaul and his father collected under a book focus on a single issue: how to be a great writer. The letters between the father and son share the news about his son's education, the father's advice on writing, and the encouragement of both son and father in creating a literary work. Except for these fundamental topics, the letters indicate almost nothing about sentimentality. Hence, it can be understood that the father intends to teach the does and don'ts to his son in his literary career. He warns him of his failures and cherishes him with his enthusiasm.

Moreover, not only the letters but also the novel, A House for Mr Biswas, bear the same tendency. Like his father's letters, in his novel, Naipaul gives the relationship between Mr Biswas and his son Anand within the frame of education. His father wants to teach his son everything he knows and expects him to get more. For instance, "[sic] he talked to Anand about people called Coppernickus and Galilyo. And it gave him the thrill to be the first to inform Anand that the world was round and moved about the sun" (HB, 1961: p. 280), and "he made Anand recite Hindi hymns after him" (HB, 1961: p. 281). Such a connection strengthens the tie between the father and son, and thus, as stated earlier, Anand and his father experience the most intimate scene of their life when the rest of their family abandon Mr Biswas: [sic]

"Why did you stay then?"

Anand looked exasperated.

"Why?" 
"Because-" The word came out thin, explosive, charged with anger, at himself and his father.

"Because they was going to leave you alone."

For the rest of that day, they hardly spoke (HB, 1961: p. 251).

This intimate scene between father and son is nourished by the training of Anand and his future education. In the novel, Naipaul shares mostly these scenes when he wants to illustrate their relationship. As discussed above, in the novel, Anand is portrayed as he is the one who is protecting his father and responsible for him. During the scenes between father and son, it is the father who is in the need of protection, care, and control.

"Anand! Anand!"

"Yes, Pa."

"That is better. You are getting a little training now. Sit down there and call out this speech."

Anand snatched Bell's Standard Elocutionist and angrily read out some Macaulay.

"You reading too fast."

"I thought you was writing shorthand."

"You answering back too! You see what happen to you children, spending all that time at Hanuman House. Just for that, check while I read back."

"O, God!” And Anand stamped, regretting the dying day.

But the checking went on.

Then Mr Biswas said, "Anand, this is not a punishment. I ask you to do this because I want you to help me."

He had discovered, with surprise, that this sentence soothed Anand, and he always

offered it at the end of these sessions as a consolation [sic] (HB, 1961: pp. 337-8).

The quotation above wisely illustrates the unknown bias or mutual deal between father and son. Father wants his son to study and practice more, and his son is aware of this fact. Moreover, the father loves to pretend that he needs help and care to encourage his son and make him feel useful. The tiniest trick here is that son is aware of his father's intention and his so-called help; therefore, as the writer of his father's fictionalised life story, Naipaul remembers his father's constructive and stimulating force in his education.

\section{Conclusion}

As stated earlier, from the perspective of parental influence on children, the role of the modelled fathers promotes a successful child. The sensitivity of Father Naipaul has contributed a lot to the social and artistic wellbeing of Naipaul through his letters, support, and encouragement. In addition, their positive father-son relationship positively reflects his academic achievement. No matter how Mr Biswas is depicted in the novel or what Naipaul says about his father, the relationship between the father and son is beyond words and explanations. As a father, Seepersad 
is the compelling force for Naipaul in his goal to be a great writer. Not only the letters between father and son, but also the novel that his son dedicated to his father bear both the hints of a father who wants to do his best for his son's writing career and of a son who feels a debt to his father in his writing career in which a father muses his son.

\section{References}

Bates, David. (1963). Portrait Gallery: V. S. Naipaul. Sunday Times Supplement, May 26, pp. 12-13

Bingham, Nigel. (1972). The Novelist V. S. Naipaul Talks to Nigel Bingham about his Childhood in Trinidad. Listener, 88, September 7, pp. 306-7.

Easterbrooks, M. A., \& Goldberg, W. A. (1984). Toddler development in the family: Impact of father involvement and parenting characteristics. Child Development, 55, 740-752.

Lamb, M. E. (2010). The role of the father in child development (5th ed.). Hoboken, NJ: John Wiley and Son

Morman, M. T., \& Floyd, K. (2002). A “changing culture of fatherhood”: Effects on affectionate communication, closeness, and satisfaction in men's relationship with their fathers and their sons. Western Journal of Communication, 66, 395-411.

Naipaul, V.S. (1961). A House for Mr Biswas. London: Andre Deutsch.

Naipaul, V.S. (1984). Finding the Centre: Two Narratives. London: Andre Deutsch.

Naipaul, V.S. (1957). The Mystic Masseur. London: Andre Deutsch.

Naipaul, V.S. (2000). Letters Between a Father and Son. London: Abacus.

Pleck, J. H. (2010). Fatherhood and masculinity. In M. E. Lamb (Ed.), The role of the father in child development, 5th ed., pp. 27-57. Hoboken, NJ.

Singer, A. T. B., \& Weinstein, R. S. (2000). Differential parental treatment predicts achievement and self-perceptions in two cultural contexts. Journal of Family Psychology, 14, 491-509.

Vogt, G. M., \& Surridge, S. T. (1991). Like son, like a father: Healing father-son wounds in men's lives. New York, NY: Plenum Press.

\section{Destek ve Teşekkür Beyanı:}

Çalışma herhangi bir destek almamıştır. Teşekkür edilecek bir kurum veya kişi bulunmamaktadır.

\section{Çıkar Çatışması Beyanı:}

Çalışma kapsamında herhangi bir kurum veya kişi ile çıkar çatışması bulunmamaktadır. 